\title{
Stat og subjektivitet i klasseanalysen
}

\author{
Tage Bild og Jens Hoff
}

\section{Nogle overvejelser foranlediget af Finn Dam Rasmussens artikel i Kurasje nr. 37}

Klassebegrebet er vel nok det af den marxistiske teoriverdens begreber, som har været i kraftigst krydsild gennem de seneste 10-15 år.

Årsagen hertil synes at være kombinationen af voldsomme samfundsmæssige strukturforandringer ${ }^{1}$ og de store ambitioner, der ofte knyttes til klassebegrebets forklaringskraft mht. politisk handlen og samfundsmæssig forandring.

En afklaring af begrebets status er derfor nu, måske mere end nogensinde før, påkrævet.

Af samme grund er det glædeligt, at Kurasje har taget denne debat op, bl.a. i form af Finn Dam Rasmussens (nedenfor FDR) artikel i Kurasje nr. 37. Finn Dam Rasmussens artikel rummer dels en gennemgang og kritik af undertegnedes bidrag til en antologi om velfærdsstatens klasser ${ }^{2}$, såvel som nogle generelle overvejelser om klasseteoriens genstandsfelt og sammenhængen mellem klasser, livsform og subjektivitet. Selvom FDR i nogen grad overser vore bidrags tentative karakter og på visse punkter klart over- eller misfortolker vore udsagn, er hensigten her kun i begrænset omfang at gå ind i en polemik. Vi skal således i det følgende først og fremmest koncentrere os om nogle af de væsentlige spørgsmål FDR rejser i sin artikel; nemlig spørgsmålene om klasse og subjektivitet, om udbytning og produktionsmåder samt om statens karakter; i håb om at fremme en fælles forståelse af disse forhold.

\section{Klasse og subjektivitet}

Hvad er klasseteoriens 'genstandsfelt' og hvad er rækkevidden af dens udsagn, spørger FDR i ovennævnte artikel, hvor det samtidigt antydes, at klassebegrebet er 'overbelastet' fordi det forsøger at indløse en ambition om på en og samme gang at begribe samfundets socialøkonomiske struktur og samfundsmedlemmernes sociale handlen.

Lad os forsøge at se nærmere på disse to problemer.

1. For nærmere redegørelse for disse strukturforandringer i især arbejderklassen og deres politiske konsekvenser, se Hoff og Goul Andersen 1986.

2. J. Hoff (red.) 1985 b. 
I marxismen er klassebegrebet uløseligt knyttet til spørgsmålet om den sociale orden. Forsøget på at forstå dennes reproduktion eller forandring må siges at være klasseteoriens oprindelige erkendelseshensigt ${ }^{3}$. Klassekampen ses således som dynamoen i al samfundsmæssig forandring, eller som det element, der tilføjer en »statisk « socialstruktur dens dynamik. Man kan, med C. Offe (1985), hævde, at den grundlæggende påstand i klasseteorien er, at der samtidigt med eksistensen af hvad han kalder den »reproduktive sløjfe« (udgangsstruktur-(individuel)handlen-reproduktion), eksisterer en »transformativ sløjfe « (udgangsstruktur - (kollektiv) handlen strukfurforandring). Under kapitalistiske produktionsforhold arbejder arbejderne ikke bare, de vil også organisere sig mod udbytningen af deres arbejdskraft.

Kapitalisterne rationaliserer ikke blot akkumulationsprocessen, de irrationaliserer og desorganiserer den også, hvorved de bestandig undergraver de kollektive betingelser for fremtidig akkumulation og dermed deres egen eksistens som klasse.

Problemet for klasseanalysen er imidlertid, at forholdet mellem »udgangsstrukturen«, dvs. produktionsforholdene og subjektivitet og kollektiv handlen altid har været underteoretiseret. Hos Marx selv optræder individerne i den »reproduktive sløjfe« som viljeløse, feticherede karaktermasker, mens de i den »transformative sløjfe« pludselig griber historien. Her falder karaktermaskerne og subjektiviteten skaber historien.

Dette spring sker hos Marx temmeligt uformidlet, og mange af de teorier, der senere er opstillet for at forklare dette spring lider af, hvad der noget slagordsagtigt, er blevet kaldt » $\varnothing$ konomisme« eller »klassereduktionisme«.

Økonomismen repræsenteres i denne forbindelse af den klassiske »klassen-an-sich «, »klassen-für-sich « model, som Marx iøvrigt selv introducerede i »Filosofiens elendighed $\aleph^{4}$. Det er ikke her nødvendigt at komme nærmere ind på denne opfattelse, blot skal det påpeges, at i både den deterministiske (2. Internationales) og den voluntaristiske (Lenins) version, fremtræder såvel subjektivitet som kollektiv (klasse-) handlen hovedsageligt som epifænomener; som nødvendige politiskideologiske spejlinger af individets eller klassens »objektive«, dvs. økonomiske, placering.

Klassereduktionismen repræsenteres af Korsch (1974) og Lukacs (1971) og i moderne version af Poulantzas $(1973,1977)$. Disse forfattere bryder med $\emptyset$ konomismen, idet det tillægger det politiske og ideologiske niveau en »relativ autonomi $\ll$ og egen efficiens, men der forbliver dog $\varnothing$ konomistiske reminiscenser i teorien, idet de politiske og ideologiske praktikker altid spores tilbage til de bevidste klassesubjekter, hvis handlinger er betinget af den klassebevidsthed

3. En henvisning til »Det Kommunistiske Manifest« skulle være tilstrækkelig.

4. Se K. Marx (dansk udgave 1974). 
(eller de klasseinteresser), de har fået tillagt i kraft af deres placering af produktionsforholdene.

Heroverfor repræsenterer gramscianismen og neo-gramscianismen et egentligt brud ${ }^{5}$. Her konstitueres subjektiviteten og den kollektive handlen ikke mere a priori qua individernes økonomiske klassetilhørsforhold. Subjektet eller subjektiviteten konstitueres derimod først og fremmest gennem ideologiske og politiske praktikker. Subjektiviteten er ikke forudbestemt i kraft af de $\varnothing$ konomiske relationer (kategorier) eller konstitueret igennem ideologier, som på forhånd antages at have et bestemt klassetilhørsforhold.

Dette brud repræsenterer for os at se en vigtig åbning i klasseteorien, og har da også vidtrækkende konsekvenser for teorier om kollektiv handlen og ideologi, som vi imidlertid kun har begrænset mulighed for at komme ind på her ${ }^{6}$.

Problemet i denne teoridannelse er imidlertid, at den i sin iver for at gøre op med $\varnothing$ konomismen helt afskærer sig fra en diskussion af den $\varnothing$ konomiske klasseplacerings betydning for subjektiviteten (eksempelvis det fremmedgjorte lønarbejdes betydning). Dette forhold må naturligvis også inddrages i en teori om subjektivitet, og en sådan må derfor tage sit udgangspunkt i at subjektiviteten skabes i et kompliceret samspil mellem økonomisk klasseplacering, arbejdsforhold, ideologiske og politiske praktikker (aktiviteter og institutioner), livsformer og kultur.

Det er således vigtigt at være opmærksom på, at partier, bevægelsers og gruppers ideologier og politiske handlen i stor udstrækning formidler og former sammenhængene mellem økonomisk klasseplacering, kultur/livsform og subjektivitet/(politisk) bevidsthed. Det betyder også, at vi ikke ser nogen automatisk eller deterministisk sammenhæng mellem disse størrelser.

Vi vil her endog gå skridtet videre og argumentere for, 1) at det er afgørende nødvendigt at tage et opg ør med a priori priviligeringen af klasser som sociale aktører, og, i forlængelse heraf, 2) at det er nødvendigt at begrænse klassebegrebet til at angå individernes placering i modsætningsforhold i produktionen, hvis man vil bevare et klassebegreb med en vis udsagnskraft i forhold til sociale modsætninger og politiske kampe.

Opgøret med a priori priviligeringen af klasser som sociale aktører er nødvendig af to grunde:

a) en teoretisk begrundelse. Med a priori priviligeringen af klasser som sociale aktører foretages koblingen mellem klassebestemmelsen og klassehandlen altid v.hj.a. klasseinteresse-begrebet. Individet/bevægelsen/partiet foretager sig en bestemt handling, fordi det har en bestemt klasseinteresse. At

5. Se f.eks. Gramsci (1971), C. Mouffe (1979), E. Laclau (1977).

6. For en grundigere behandling, se f.eks. B. Jessop (1982) pp. 191-210 eller J. Hoff 1985a. 
forudsætte en sådan »rationel adfærd « hos en aktør i et struktureret socialt felt er imidlertid uhyre problematisk, og opfattelsen har da også været udsat for en omfattende og berettiget kritik indenfor f.eks. organisationsteorien ${ }^{7}$. Det synes således erkendelsesmæssigt betydeligt mere givende at analysere de enkelte organisationers eller partiers strategier under bestemte forudsætninger ${ }^{8}$, fremfor at forsøge at måle partiets/organisationens større eller mindre afvigelser (og dets eventuelle forræderi) i forhold til den »objektivt givne « klasseinteresse.

b) en empirisk begrundelse. Det er blevet stadig vanskeligere at hævde, at den mangfoldighed af partier, bevægelser, smågrupper og enkeltpersoner vi ser optræde på den politiske scene alle er klassekræfter eller udtrykker bestemte klasse- eller fraktionsinteresser. Kun ved at $\varnothing$ ve vold på virkeligheden (eller på klassebegrebet) kan denne mangfoldighed presses ind i klasseanalysens kategorier.

En løsning på dette problem er, som hos neo-gramscianerne, i udgangspunktet at se alle politiske og sociale kræfter som inter-klasse (bedre: mange-klasse; fransk: »pluriclassiste «) kollektive viljer konstitueret i og ved ideologisk kamp. Formatet her tillader ikke en uddybning af denne opfattelse ${ }^{9}$, men den forekommer os adskilligt bedre egnet til at forstå det kaotiske mønster af sociale modsætninger og politiske kampe end en stædig fastholden af klasser som de primære politiske aktører; selvom neogramscianernes opfattelse heller ikke er uden problemer ${ }^{10}$.

På samme måde, som man ikke a priori kan antage, at klasser er de eneste eller væsentligste sociale aktører, kan man heller ikke a priori tale om en bestemt klassekultur eller bestemte klasselivsformer. Sammenhængen mellem $\emptyset$ konomiske eksistensbetingelser, kultur, subjektivitet og kollektiv handlen er ikke tilfældig (se nedenfor), men heller ikke deterministisk og forskellige udfald af formidlingsprocesserne er mulige.

Klasse opfattes således med fordel som et hypotese-genererende begreb, hvor de økonomiske eksistensbetingelser (udstikker individets / gruppens muligheder/begrænsninger (kapacitet) for at indgå i bestemte kulturelle mønstre/ livsformer, for en bestemt subjektivitetsdannelse og for bestemte former for individuel/kollektiv handlen under bestemte historisk-politiske betingelser. Der kan i bestemte lande på bestemte tidspunkter være en ganske stærk overlapning mellem gruppedannelserne på de forskellige niveauer, men pointen her er, at en sådan overlapning ikke kan antages a priori, men må undersøges systematisk-empirisk. Vores betragtningsmåde har således den fordel, at den

7. Se f.eks. M. Crozier og E. Friedberg 1980.

8. For fors $\emptyset$ g i denne retning, se f.eks. B. Jessop (1983), hvor der tales om forskellige konkurrerende »akkumulationsstrategier

9. For en sådan, se Laclau og Mouffe op.cit., samt begge: »Hegemony and Socialist Strategy«. London 1984.

10. For en problematisering af denne opfattelse, se B. Jessop op.cit. pp. 191-210. 
åbner disse sammenhænge for empirisk forskning, hvor de før for ofte har henligget i forhåndsantagelsernes og postulaternes halvmørke ${ }^{11}$.

Den betragtningsmåde vi her har anlagt på sammenhængene mellem $\varnothing$ konomisk klasseplacering, kultur, livsform og subjektivitet svarer på mange måder til den opfattelse FDR fremlægger i ovennævnte artikel (pp. 102-105). De konklusioner vi har draget af analysen mht. klassebegrebet går imidlertid i modsat retning.

FDR mener således ikke, at der kan finde en klassebestemmelse sted på det $\varnothing$ konomiske niveau (»Analysen af værdikategorierne i kapitalkredsløbet er altså ikke en klasseanalyse, heller ikke nogen »økonomisk klassebestemmelse ...« p. 102), men at de økonomiske kategorier (værdikategorierne) udgør klassens specifikt formede »økonomiske eksistensbetingelser«. På baggrund heraf finder der så en klassedannelse sted på livsform-kulturniveauet og på bevidstheds- og den kollektive handlens niveau. »Klassedannelse i denne betydning kan kun ske som en social bevægelse, og må derfor ses i en permanent proces af dannelse, opløsning og nydannelse« (p. 103).

Denne opfattelse er imidlertid problematisk af to grunde:

1) FDR tager Marx til indtægt for, at der programmatisk må sondres mellem økonomiske kategorier, dvs. værdikategorierne (lønarbejde, kapital, jordrente) og sociale klasser, og afviser hermed at placering i produktionsforholdene kan definere en klasse (jvf. ovenfor: »analysen af værdikategorierne ... er ikke en klasseanalyse); den kan højst gøre krav på at udgøre klassens »økonomiske eksistensbetingelser«.

Værdikategorierne er imidlertid elementer i Marx' analyse af den abstrakte (»rene«) kapitalistiske produktionsmåde. Her anvendes de i analysen af kapitalens såkaldte $\emptyset$ konomiske lovmæssigheder, og produktionsforholdenes magtaspekter eller sociale relationer er her reduceret til en ceteris paribus forudsætning. Mens et sådant analytisk fif kan være tilladt, når man analyserer akkumulationsproces og profitrate på højt abstraktionsniveau, går det ikke når man vil analysere klasser. Her må man lægge vægt på, at produktionsforholdene udover at rumme en udbytnings- og værdifordelingsproces også rummer dimensioner af dominans, kontrol og autonomi, som er afgørende for at denne proces kan finde sted, og som reproduceres (eller transformeres) under akkumulationscyklus'en. Når Marx hævder, at der må sondres mellem værdikategorier og sociale klasser er det derfor næppe fordi han mente, at produktionsforholdene udgjorde et dårligt udgangspunkt for en klasseanalyse, men snarere fordi han mente, at klasseanalysen burde finde sted på et andet og lavere abstraktionsniveau.

11. Dette også jvf. Giddens, der skriver: ».... the most important blank spots in the theory of class concern the processes whereby »economic classes « become »social classes « and whereby, in turn, the latter are related to other social forms. (Giddens 1973, p. 105). 
Det vi er vidne til hos FDR er således en niveaufejlslutning (af typen: fordi værdikategorierne i den abstrakte kapitalistiske produktionsmåde ikke duer som udgangspunkt for en klassebestemmelse, kan man heller ikke anvende produktionsforholdene i de historisk forekommende produktionsmåder som udgangspunkt for en sådan); en niveaufejlslutning som formodentlig befordres af, at FDR begrebsligg $\varnothing$ r produktionsforhold som rent $\varnothing$ konomiske kategorier ${ }^{12}$.

2) Hos FDR forbliver klassebegrebets forklaringsværdi mht. f.eks. subjektivitet eller politisk handlen helt uafklaret. Hvordan bliver det muligt at etablere nogen form for kausalitet, når klassedannelsen, som FDR skriver »må ... ses i en permanent proces af dannelse, opløsning og nydannelse« (p. 103)?

Hvis arbejderklassen idag er forskellig fra arbejderklassen igår, som igen vil være forskellig fra arbejderklassen imorgen, bliver det meget svært at se i hvilket omfang det at tilhøre arbejderklassen kan forklare subjektivitetsdannelse eller politisk adfærd.

Endnu værre bliver det, når FDR også vil inddrage geografi, race og køn i klassebestemmelsen (p. 103), og helt slemt bliver det hvor han skriver, at »Da klassedannelse forstås som en social bevægelse, er kampe og konflikter vigtige klassedannende faktorer « M.a.o. i en situation uden kampe og konflikter er klasser ikke-eksisterende, eller ....?

De problemer FDR her prøver at tackle er naturligvis reelle nok, nemlig dels problemet om forandringer i klassestrukturen og dels problemet med sammenhængen mellem » $\varnothing$ konomiske eksistensbetingelser « og subjektivitet og politisk handlen. Det er imidlertid vores opfattelse, at ingen af disse problemer finder en tilfredsstillende løsning medmindre man fastholder, at klassebestemmelsen sker via produktionsforholdene, som igen må ses som forankrede i samfundsstrukturen. Samfundsstrukturens $\varnothing$ konomiske og politiske institutioner er udsat for konstante forandringsfors $\varnothing \mathrm{g}$, bl.a. af de forskellige sociale kræfter og bevægelser, men er dog i lange perioder præget af permanens og stabilitet; perioder som kan begribes ved hjælp af begreberne »akkumulationsmodel« (Amin 1974) eller »hegemoni« (Gramsci 1971). Det er derfor ikke rigtigt, at vi er vidne til en konstant transformation af hverken samfundsstruktur eller klasser. Netop fordi vi ikke er det, kan en klasseanalyse på et givet tidspunkt tage udgangspunkt i sådanne (for klasseanalysen) givne »akkumulationsmodeller« eller »hegemoniske projekter«. I modsat fald; dvs. hvis klasse ikke betegner en struktur eller en samfundsmæssig konfiguration af en vis permanens og varighed bliver det meget svært at få øje på klassebegrebets eksistensberettigelse i samfundsanalyser.

Dette betyder også, at på et givet tidspunkt er klassebestemmelsen entydig og kausalitetsforholdet må anses for givet (fra produktionsforhold/

12. Man kan derfor diskutere hvis analyse det er, der er »rig på dogmatiske marxistiske antagelser « (implicitte såvel som explicitte), som FDR skriver om vores analyse. 
klassebestemmelse (årsag) til subjektivitet/politisk handlen (effekt)). Derimod har FDR naturligvis ret $i$, at der i et længere tidsperspektiv er tale om en dialektisk proces, hvor kollektiv handlen, sociale kampe og konflikter kan ændre klassestrukturen ${ }^{13}$.

Det skulle nu være klart, at de beskyldninger FDR retter mod os i ovennævnte artikel, for »helt at udrydde feltet for en subjektivitetsteori« (p. 94), beror på en grov overfortolkning. I artiklen om »Velfærdsstatens genealogi og de offentligt ansatte « forsøges analysen således bevidst holdt på niveauet: produktionsmåde og produktionsforhold, og livsform, subjektivitet og kollektiv handlen diskuteres ikke her, da det netop, som FDR påpeger, ville kræve betydeligt mere omfattende analyser ${ }^{14}$.

\section{Produktionsmåde og udbytning}

Mht. spørgsmålet om produktionsmåder og udbytning er der afgørende meningsforskelle mellem FDR og undertegnede. Disse meningsforskelle beror for os at se dybest set på FDR's fastholden af dels, som påpeget i forrige afsnit, at det korrekte analyseniveau (også) hvad angår produktionsmåder og udbytning er det almene kapitalbegreb, og dels af, at kapitalismen i virkeligheden ikke har gennemgået væsentlige kvalitative forandringer siden Marx' tid. Økonomien bibeholder, iflg. FDR, sine grundlæggende modsigelser; blot får de en anden fremtrædelsesform når de reproduceres i f.eks. statsligt regi $i^{15}$.

Heroverfor står vores opfattelse af, at den interventionistiske eller »postfordistiske« samfundsformation må forstås som en kvalitativt ny kapitalistisk reproduktionsform, hvilket, mht. anvendelsen af de marxske værdikategorier betyder, at disse ikke kan anvendes mekanisk, men at man må fremstille begreber, som under anvendelse af marxske metode modsvarer den udviklede kapitalismes ændrede karakter.

Formatet her tillader kun i begrænset omfang en videreudvikling af denne argumentation, men for vores synspunkt taler det forhold, at Marx' overfladiske og selvmodsigende analyse af de såkaldte »cirkulationsfunktioner« næppe kan siges at udgøre et særligt godt grundlag for den teori om servicesektorens

13. Den form for kausalitet vi her forsøger at indkredse er blevet kaldt »systemkausalitet« eller »strukturel kausalitet«, og indebærer at man tænker sig årsager og effekter som værende gensidigt afhængige (interdependente) indenfor et system, hvis egenskaber gør det muligt at forstå (og til en vis grad forudsige) de resultater, som skal forklares.

14. Det er således bevidst, at jeg skriver (p. 128): »... der er derfor en ægte materiel basis for modsatrettede interesser $\mathrm{i} »$ toppen « og i »bunden« af den offentlige sektor«, og ikke f.eks.: »der eksisterer derfor modsatrettede interesser mellem ...«. Dette er netop et fors $\emptyset \mathrm{g}$ på at pointere, at interesser ikke følger automatisk eller deterministisk udfra placering i produktionsforholdene.

15. Jvf. p. 91 hvor FDR skriver: »En analyse af velfærdsstatens genesis og af dens systematiske sammenhæng med den kapitalistiske reproduktion vil vise, at den er opstået og kun kan reproduceres i sin komplementaritet til kapitalforholdets udfoldelse«. 
og statens politiske $\varnothing$ konomi, som i lyset af kapitalismens udvikling er stærkt påkrævet. ${ }^{16}$

Centralt i vores analyse står en antagelse om videnskabens stærkt $\emptyset$ gede betydning i den kapitalistiske produktion og hermed et stadig skarpere skel mellem manuelt og intellektuelt arbejde. Den nødvendige viden er blevet stadig mere specialiseret og formaliseret i form af professionelle og faglige organisationer, et omfattende uddannelsessystem og institutionernes uddannelseskrav.

Med den øgede statsintervention, særligt i de såkaldte velfærdssamfund, er denne tendentielle »selvstændiggørelse « af videnskaben accelereret kraftigt, dels fordi disse velfærdsfunktioner i sig selv kræver en del specielt uddannet personale, men også fordi det offentlige via universiteter og tekniske akademier og skoler i stor udstrækning bestemmer tilgangen til forskellige fag, samt i reglen har en vis indflydelse på indholdet af den ydelse den uddannede skal levere.

Denne udvikling, som Marx ifølge sagens natur havde svært ved at forudse, selv om han var meget opmærksom på videnskabens rolle blandt produktivkræfterne, rokker ved to vigtige elementer i hans samfundsteori, nemlig værdiloven og hans udbytningsbegreb. Disse hviler bl.a. på, som det fremgår flere steder i hans arbejder, en opfattelse af at der sker en egalisering af arbejdet under kapitalismen, dvs. at alt arbejde tenderer mod at få samme værdi ${ }^{17}$, eller at alt arbejde ialtfald teoretisk kan reduceres til »simpelt arbejde «.

Hvad denne forudsætning betyder for Marx' udbytningsbegreb er blevet unders $\varnothing \mathrm{gt}$ af J. Roemer (1982a, b og c), der viser, at hvis produktionens agenter har forskellige færdigheder/kvalifikationer, eller udbyder en forskellig mængde arbejdskraft, så ophører det marxske udbytningsbegreb med at give nogle socialt meningsfyldte resultater. Forholdet mellem $\varnothing$ konomisk velfærd på den ene side og positionen som udbytter (køber af arbejdskraft) eller udbyttet (sælger af arbejdskraft) på den anden side forbliver ubestemt, dvs. udbytteren fremtræder ikke nødvendigvis som »rig « og den udbyttede som »fattig « (i pengetermer).

Dette leder R. til at påpege, at der er et skisma i den marxistiske udbytningsteori, hvor der i stedet for en type af udbytning under kapitalisme snarere er tale om at udbytningen har 2 dimensioner. R. sondrer således mellem hvad han kalder »kapitalistisk « udbytning og hvad han kalder »marxistisk « udbytning (vel egentlig: hvad marxister normalt betragter som udbytning). Den kapitalistiske udbytning kommer i stand pga. det forskellige eje af produktionsmidlerne. Målestokken - den etiske standard - er således en ligelig fordeling af produktionsmidlerne, og arbejderne betragtes som udbyttede fordi de ikke har

16. Se f.eks. F. Valentin 1978.

17. »Kvantiteten alene afgør alt, time mod time, dag mod dag: men denne egalisering af arbejdet er på ingen måde et værk af hr. Proudhons evige retfærdighed. Den er simpelthen et resultat af den moderne industri«. K. Marx 1974, p. 127. 
adgang til deres pr. capita andel af produktionsmidlerne. Ved marxistisk udbytning forstår R. den gængse merværdi-definition af udbytning, hvor arbejdere er udbyttede i det omfang de er merværdiproducerende (eller merarbejdende). I simple produktionsmodeller, hvor arbejdet er homogent og tillagt alle i lige grad er de to definitioner sammenfaldende, mens merværdidefinitionen af udbytning i det tilfælde produktionens agenter har forskellige færdigheder/ kvalifikationer som nævnt giver svært tolkelige resultater.

Af samme grund mener R., at det mest fornuftige er at knytte spørgsmålet om udbytning under kapitalismen til ejendomsrelationen og ikke til merværdirelationen, idet man så ikke længere er tvunget til at hævde, at kapitalismen ser ud som det specialtilfælde, hvor arbejdet er homogent og tillagt alle i lige grad.

Vi har i vores analyse valgt at følge R. på dette punkt, idet vi mener at egaliseringsforudsætningen er urimelig at arbejde $\operatorname{med}^{18}$. Vi anvender derfor også hans definition af udbytning, der siger, at »en person er udbyttet når vedkommende ikke kan købe varer, som repræsenterer lige så meget arbejdskraft (arbejdstimer) som vedkommende selv har bidraget med i produktionsprocessen«. »Hermed forlades«, som FDR konstaterer (p.88), »det specifikt marxske udbytningsbegreb (men altså kun i det omfang man definerer det udfra merværdirelationen). Det er iøvrigt, iflg. FDR »helt legitimt« (loc.cit.). Det virker derfor noget malplaceret, når han på den følgende side tager os i skole fordi vore udsagn om udbytning i den offentlige sektor »i forhold til merværdibegrebet er meningsløse (p. 89). Altså: enten må man acceptere, at vi forlader merværdidefinitionen af udbytning, og hvad dermed følger (bl.a. at vore udsagn »i forhold til merværdibegrebet er ... meningsløse«), eller også må man allerede fra start betragte vores udgangspunkt som illegitimt ${ }^{19}$. Hvad FDR præsterer her er kritik uden logik.

Problemet ved R.'s (og Wrights (1985)) nye udbytningsbegreb, hvor udbytning er baseret på besiddelse af ressourcer af forskellig art, er at de herigennem stærkt tilnærmer sig neo-weberianerne, hos hvem et udbytningsforhold kan etableres udfra besiddelsen af en næsten hvilken som helst ressource (se f.eks. Parkin 1979). R. og især Wright forsøger imidlertid at afgrænse sig overfor disse ved at fastholde, at udbytning kun kan etableres udfra besiddelsen af »produktive ressourcer«. Herved forstår de, hvad der dog ikke altid er lysende

18. Egaliserings-forudsætningen hviler således også på en antagelse om fuld konkurrence. Denne forudsætning er ikke på arbejdsmarkedet, lige så lidt som på varemarkedet, realistisk i kapitalismens nuværende fase. På markedet for arbejdskraft har vi tværtimod været vidne til opbygningen af en række ret effektive videns- og erhvervsmonopoler. For en eksemplificering, se T. Nilssons bidrag i J. Hoff (red.) (1985b). Se også T. Johnson 1972.

19. Misforståelsen skyldes muligvis, at jeg i omtalen af udbytning i den offentlige sektor anvender ordene »merværdiproducerende « og »merværdiflows «. Her burde jeg naturligvis følgerigtigt have anvendt ordene $»$ merarbejdende $\ll$ og $»$ merarbejdsflows $«$. Hoff op.cit. p. 127. 
klart i deres analyser, ressourcer som er strategisk vigtige for den kapitalistiske produktions- og reproduktionsproces. Det drejer sig således først og fremmest om ressourcer i form af produktionsmidler (eje eller ikke-eje) og ressourcer knyttet til arbejdskraften, dvs. først og fremmest dens kvalifikationer (uddannelse).

Herudover opererer Wright med hvad han kalder »organisationsressourcer «, og vi har i vores analyse - måske for ukritisk - fulgt Wright i hans udskillelse af denne type ressource som en selvstændig dimension i klassebestemmelsen. I det omfang denne ressource er knyttet til særlige kompetancer mht. organisation (management, forskellige typer af styring o.lign.) er det svært at se hvad der adskiller den fra andre særlige uddannelseskompetancer.

Wright udtaler sig, formodentlig af samme grund, noget svævende om hvad der ligger i begrebet »organisationsressourcer $\aleph^{20}$, men de synes for ham nærmest at være knyttet til organisationen som sådan, dvs. til positionen eller stillingen snarere end til personen. »Organisationsressourcer« bliver herved nærmest en dimension af ejet af produktionsmidlerne, og hvad Wright i realiteten $g \varnothing \mathrm{r}$ her, er derfor at smugle sine kontrolbegreber fra sin oprindelige klasseanalyse ind i denne »rethinking « af klasseanalysen. (Det drejer sig om kontrol med produktionsmidlerne, kontrol med arbejdskraft - kontrolformer knyttet til rådigheden over produktionsmidlerne; modsat det $\varnothing$ konomiske eje, se Wright 1978). Vi vil mene, at disse kontrolbegreber er både nødvendige og anvendelige $\mathrm{i}$ en klasseanalyse, blot må man naturligvis præcisere, at det er sådanne man anvender. En sådan præcisering er hermed foretaget på egne og Wrights vegne.

En kritik der, bl.a af undertegnede (Hoff 1985 pp. 125-126, se også Offe op.cit. p. 86) er blevet rettet mod Roemers og Wrights udbytningsrelationer, er at forholdet mellem dem er uklart. Det skyldes især en manglende redegørelse for hvorledes den historiske sammenhæng mellem produktionsmiddelressourcer, kontrol/organisationsressourcer og uddannelsesressourcer har udviklet sig, og for hvordan besiddelsen af uddannelses- og kontrolressourcer er kommet til at udgøre et underlag for udbytningsrelationer.

Analysen her giver en mulighed for at udbrede denne mangel, idet den peger på, at »selvstændiggørelsen « af kontrol- og uddannelsesressourcer er nøje knyttet til udviklingen af den sociale arbejdsdeling.

Udviklingen af kontrolressourcerne er således knyttet til udviklingen af kapitalens funktion. Her er udviklingen gået fra en situation hvor både

20. Han skriver således: »Of course there is an interdependence between organization and these other assets, just as there is an interdependence between means of production and skills. But organization - the conditions of coordinated cooperation among producers in a complex division of labour - is a productive ressource in its own way (Wright 1985). 
de det $\varnothing$ konomiske eje og rådigheden, dvs. kontrollen med produktionsmidler og arbejdskraft, var koncentreret i fabriksherrens person, over adskillelsen af disse funktioner gennem aktieselskabsformen, til den moderne virksomhedstype, hvor selv rådigheden er splittet op mellem et antal stadig mere specialiserede ledere på forskellige niveauer og med forskellige kompetancer.

Udviklingen af uddannelsesressourcerne er knyttet til udviklingen af den kollektive arbejders funktion, hvor det høje videnskabelige eller teknologiske indhold i arbejdsprodukterne i den moderne industri har nødvendiggjort en stadig større stab af teknikere, ingeniører og forskere på alle niveauer, og samtidig reduceret den nødvendige manuelle arbejdsstyrke.

Der er m.a.o. sket det, at den teknologiske og organisatoriske ekspertise er blevet stadig mere strategisk vigtig for den kapitalistiske produktions- og reproduktionsproces. Dette placerer såvel kapitalen, som det Øvrige samfund, i en afhængighedsposition af særlige kompetencer indenfor disse områder; en afhængighed der naturligvis af indehaverne af disse kompetancer omsættes i (især) lønmæssige privilegier.

Denne udvikling af hhv. kapitalens og den kollektive arbejders funktion indebærer dog ikke automatisk, at kontrol- og uddannelsesressourcer ligestilles med besiddelsen af produktionsmiddelressourcer, hvad vi da også understreger (se Hoff 1985, p. 126).

En $100 \%$ »selvstændigg ørelse« af disse kontrol- og uddannelsesressourcer, således at de kan komme til at udgøre omdrejningspunktet i egentlig nye produktionsmåder, således som f.eks. Wright hævder er tilfældet, kræver således omfattende ændringer i den kapitalistiske stats fundamentale retsprincipper ændringer som kun i begrænset omfang er fulgt i kølvandet på den tendentielle »selvstændiggørelse « af disse ressourcer. Wright og Roemers udbytningsbegreber således både kan og bør indplaceres i en teori om udviklingen af den sociale arbejdsdeling under kapitalismen. En sådan samlet teori er endnu svagt udviklet, men der findes dog en anseelig mængde litteratur omkring delaspekter heraf ${ }^{21}$.

Af ovennævnte grunde vil vi derfor fastholde, at den moderne kapitalismes klasser kan analyseres meningsfyldt udfra hhv. produktionsmiddel-, kontrol-, og uddannelsesdimensionerne. Herudover kræver en analyse af den moderne kapitalisme også en præcis afgrænsning af klasseanalysens gyldighedsområde. Især må spørgsmålet om i hvilket omfang klasseanalysens kategorier kan anvendes på den offentlige sektor afklares, hvilket er emnet for næste afsnit.

21. Se f.eks. H. Bravermann 1971, R. Edwards 1979. M. Burawoy 1982, N. Abercrombie og J. Urry 1983. 


\section{Spørgsmålet om statens karakter}

I forsøget på at placere de statsansatte og -understøttede i en klasseteoretisk ramme arbejder vi begge ud fra den antagelse, at staten må forstås som udtryk for en »social relation sui generis«, dvs. en relation af egen art, der hverken afspejler eller lader sig udlede af de kendte relationer mellem kapital og arbejde.

Denne åbne og egentlig meget beskedne antagelse provokerer FDR og får ham flere steder til at efterlyse en »begrebsliggørelse af den kapitalistiske stat«. Det er vores indtryk at FDR på dette punkt misforstår vores intention, hvilket fører til en lang, kompliceret kritik, som vi ganske vist har læst med interesse, men som vi på den anden side ikke rigtig ved hvad vi skal stille op med, fordi hans tolkning flere steder producerer betydninger, som vi ikke selv har lagt i ordene ${ }^{22}$.

Der er altså grund til at præcisere, hvad vi lægger - navnlig ikke lægger - i antagelsen om staten som udtryk for en særlig relationstype. I de sammenhænge hvor udtrykket er brugt, fungerer det blot som en art »positionsangivelse« i forhold til traditionel marxistisk statsteori. Denne foreløbigt helt åbne og bevidst mangetydige position tjener kun som heuristisk afsat for afprøvning af ikke på forhånd fastlagte teoretiske ræsonnementer om den voksende statssektors placering i den moderne klassestruktur. Artiklen om »Velfærdsstatens genealogi og de offentligt ansatte« $(\mathrm{JH})$ repræsenterer således en afprøvning af, hvad der kommer ud af at betragte staten som en »transkapitalistisk «st $\varnothing \mathbf{r}-$ relse, der rummer spændinger mellem forskellige rationalitets- og organisationsprincipper. Artiklen om »De økonomisk overflødige« (TB) afprøver, hvad der kommer ud af at betragte statslig afhængighed og kontrol som en klasseanalytisk komplementærrelation til kapitalforholdet, og de statsligt underst $\varnothing t-$ tede som »serie« komplementært til civilsamfundets klasser.

FDR vil forgæves kunne lede efter en fælles, implicit»formbestemmelse« af staten i disse bidrag. Den findes ikke. Der er begge steder tale om eksplorative fors $\varnothing \mathrm{g}$ på at finde ud af, hvad der sker, når staten betragtes som en struktur af egen art, der ikke lader sig »rekonstruere « ud fra læsning af Kapitalen. Det kan så naturligvis diskuteres om disse forsøg er »marxistiske« eller ej, men så længe vi er enige om at det herskende marxistiske basisoverbygnings paradigme har vist sig inadækvat til en klasseteoretisk analyse af de statsansatte/understøttede, er dette spørgsmål af beskeden interesse. Forsøgene er nødvendige.

I artiklen om de økonomisk overflødige skitserer vi et muligt alternativ til basis-overbygnings modellen, som FDR for egen regning kalder en »ordens-model «, og som han karakteriserer på følgende måde: »Den nye model siger, at ved siden af kapital-relationen eksisterer en statslig

22. F.eks. FDR's tolkning af begrebet »social orden«s. $97 \mathrm{f}$ og problematikken $»$ stand eller klasse $\ll s$. $100 \mathrm{f}$, som vi skal kommentere senere. 
relationstype, der determinerer et stratifikationsprincip, en social orden, som er alternativ til kapitalrelationens klasseforhold « (s. 97). Her er der helt klart tale om en misforståelse, som beror på at FDR ikke har forstået meningen med at betragte de to relationstyper som komplementære. Det er muligt at vi på dette centrale punkt har formuleret os for »hurtigt «, så det er der grund til at uddybe.

Vi siger ikke at statsrelationen betinger et »alternativt« stratifikationsprincip, men derimod et princip, der er komplementcert til kapitalrelationen. Med komplementaritet menes ifølge ordbogen at samme sag (med det sprog vi har til rådighed) kun fuldstændigt lader sig beskrive med begreber, der gensidigt udelukker hinanden ${ }^{23}$. Når vi således skitserer muligheden af at betragte statsog kapitalrelationen som komplementære, ligger der heri en udvidelse af begrebet »den kapitalistiske produktionsmåde« til at omfatte andet og mere end de $\emptyset$ konomirelationer, vi kan finde analyseret i Kapitalen. Produktionsmåden må, som vi skrev, begribes »som et komplementært forhold mellem bestemte $\varnothing$ konomiske udbytningsrelationer og statslige magtrelationer, som ikke kan udledes af hinanden $\aleph^{24}$.

Eller for at udtrykke det mere firkantet end vi egentlig bryder os om: Magten og det frie bytte er to aspekter af samme grundlæggende forhold, som vi med det sprog, der er til rådighed, foreløbig kun kan beskrive komplementært: tvang og frihed, stat og marked, politik og økonomi osv. - Det er indsigten i denne indre sammenhæng mellem stats- og kapitalrelationen, der får os til at påstå begrebet om komplementaritet i arbejderklassen, dvs. at »arbejder« og »understøttet« på én gang er identiske og forskellige, at arbejderklassen i den moderne velfærdsstatslige forstand altså må beskrives med de gensidigt udelukkende og hinanden supplerende begreber »klasse« og $»$ serie $\ll^{25}$.

Det er noget helt andet end det, FDR forstår med ordet »alternativ«, og misforståelsen kommer tydeligt til udtryk, når han i sin kritik spørger (og svarer): »Betyder det at seriebestemmelsen også skulle dække de offentligt ansatte? Det mener T. Bild næppe«. (s. 100). Svaret er i dette begrebssystem faktisk: både-og. Her gælder den klassifikatoriske og ubevægelige formallogik, som FDR bruger som kritisk redskab, ikke mere. Derfor er det også malplaceret at påtvinge os begrebsparret stand-klasse, som FDR partout vil have os til at vælge imellem. Hvorfor skal vi det? Dette begrebspars gyldighed refererer jo tilbage til overgangsfasen mellem før-kapitalisme og kapitalisme. Den historie gentager sig næppe. Hvad vi søger er et nyt begrebspar (klasse-serie), der

23. For en populær fremstilling af komplementaritet som erkendelsesteoretisk imperativ kan henvises til Tor Nørretranders: Det udelelige, Kbh. 1985.

24. Jens Hoff (red.), op.cit. s. 196.

25. Ibid. s. 204, se også side 199 om fremmedgørelsens komplementære former i og uden for arbejdet. 
refererer til overgangsfasen mellem kapitalisme og den nedbrydning af skellet mellem stat-civilsamfund, som de nye voksende kategorier af statsligt ansatte og underst $\varnothing$ ttede signalerer.

FDR henviser i sin kritik til en bog af Jean L. Cohen, som vi ikke har været opmærksomme på ${ }^{26}$. Den henvisning er vi taknemmelige for, fordi bogen på næsten enhver tænkelig måde underbygger nødvendigheden af en åben antagelse om statens karakter, når det drejer sig om klasseanalyse. I et afsnit om klasse og stat, hvor Cohen analyserer Marx' placering af statsbureaukratiet finder vi således følgende passage, som præcist foregriber vor egen opfattelse:

»Bevidst om at bureaukratiet ikke er en stand i den hegelianske betydning, men ude af stand til at indpasse dette stratum i klasseanalysen af civilsamfundet, refererer Marx til det som en 'kunstig kaste', rekrutteret fra overbefolkningen fra civilsamfundets forskellige klasser og opretholdt gennem skatterne, der især er pålagt bønderne. Her er der altså en spændende åbning i klasseanalysen, der peger på et historisk nyt (hverken stand eller klasse) stratifikationsprincip, som sameksisterer og konkurrerer med klasse. 'Kunstig kaste' er den måde, hvorpå Marx indrømmer, at han ikke kan redegøre for bureaukratiet i sin klasseteori; at der eksisterer en dominansstruktur og stratifikation, som undslipper klassebegrebet, men som er helt moderne.

Denne åbning virkeliggøres imidlertid aldrig i en ny teori. $\ll^{27}$

Hvis vi på forhånd havde kendt denne inspirerende Marx-kritik, havde vi måske klarere kunnet begrunde vores antagelse om »statsrelationen sui generis«. Imidlertid synes vi ikke, at det lykkes Cohen at udnytte åbningen til en »ny teori«. Konklusionen, »Toward a Critical Stratification Theory«, rummer således stort set kun en gennemgang af Habermas' »systemteoretiske referenceramme $\ll$ og forskellige analysefors $\emptyset \mathrm{g}$ baseret herpå.

Cohens fortjeneste er derimod at hun temmelig klart får vist, hvorledes den moderne statsteoretiske diskussion færdes i et begrebsligt uafklaret felt mellem to, hinanden udelukkende, yderpoler.

Den ene pol, den traditionelt »marxske«, bestemmer staten som en mere eller mindre determineret overbygning, hvis funktioner, rationalitetsprincipper og strukturer alle er bestemt af (og funktionelle for) civilsamfundets udvekslingsrelationer og klasseforhold. De fors $\emptyset$ g, der i 70'erne blev gjort med at foretage »statsudledninger « på basis af Kapitalens vareanalyse er et teoretisk »rent« eksempel på den økonomisme, der kendetegner denne pol.

Den anden pol har definitivt forladt det materialistiske imperativ om $\emptyset$ konomiens primat og opfatter den moderne kapitalisme som en systemisk

26. Jean L. Cohen: Class and Civil Society: The Limits of Marxian Critical Theory, Oxford 1983.

27. Ibid. s. 129-130. Sidste fremhævelse er vores. 
helhed, hvori staten optræder som en aktiv del, der ikke kan forstås ved at blive reduceret til civilsamfundets $\varnothing$ konomifunktioner. Habermas' begreb om samfundsstrukturen som en kompleks sammenfatning af to »subsystemer«, baseret på »medierne penge og magt«, er et godt eksempel på denne anden pol. ${ }^{28}$

Med vores begreb om »statsrelationen « som en ordensbærende relation, der er komplementær til kapitalrelationen, lægger vi os nok nærmere Habermas end de mere Marx-ortodokse statskonceptioner - uden dog at forsøge os med Habermas' eget, ofte vage og uafsluttede begrebssystem med de mange løse ender.

I vores afsøgning af mulige konsistente begrebsdannelser, der kan hjælpe til at slå bro mellem de to poler, viser der sig et helt centralt problem, som FDR med rette slår ned på. Han skriver:

»Et problem, der imidlertid dukker op i disse 'videreudviklinger' og 'ajourføringer' af klasseteorien, er bagsiden af ovennævnte problem om en opklaring af klasseteoriens udsagnsfelt. Det viser sig nemlig, at klasseteorien ikke er en gang bolledej, hvor man mere eller mindre vilkårligt kan hive og flå i alle retninger, skære fra og lægge til som det nu passer sig. Langt snarere har den karakter af et korthus, hvor én etage ikke bare kan fjernes fra det samlede bygningsværk; og hvor bygningen vakler faretruende, hvis dens grundlag udsættes for større rystelser« (s. 85). Argumentet skærpes i slutningen til, hvordan man kan forny klasseteorien og samtidig »bevare pointerne fra den kritiske marxistiske kapitalanalyse « (s. 105).

Det er en anden formulering af problemet med de hinanden udelukkende poler, som blev nævnt ovenfor. Man kunne også stille spørgsmålet sådan: Hvordan overskrides Marx' analyse af civilsamfundets udvekslings- og klasseforhold således at de statsligt ansattes og understøttedes klasserelationer indbegribes, uden at Marx' konsistente analytiske indsigt går tabt i det nye, mere omfattende begrebssystem?

Det ved vi ærlig talt ikke, kun at det er nødvendigt at eksperimentere med nye begreber og synsvinkler - og acceptere at hovedparten af de fors $\emptyset \mathrm{g}$ sikkert ender i den teoretiske skrotbunke ved siden af de gamle kapitallogiske »statsudledninger «. Hvis vi skulle nævne meningen med antologien, så er det at vise nødvendigheden af at holde $\varnothing$ jnene åbne for dette.

28. J. Habermas: »A Reply to my Critics«, in J.B. Thompson and D. Held (eds): Habermas, Critical Debates, London 1982, s. 279. 


\section{Litteraturliste.}

Abercrombie, N. og Urry, J. (1983): Capital, Labour and the Middle Classes. London.

Amin, S. (1974): Mot en strukturell kris for kapitalismen. Zenit nr. 37.

Bravermann, H. (1971): Labor and Monopoly Capital. New York.

Burawoy, M. (1979): Manufacturing Consent. Chicago.

Cohen, J.L. (1983): Class and Civil Society: The Limits of Marxian Critical Theory. Oxford.

Crozier, M. og Friedberg, E. (1980): Actors and Systems. The Politics of Collective Action. Chicago.

Edwards, R. (1979): Contested Terrain. New York.

Giddens, A. (1981): The Class Structure of the Advanced Societies. London.

Gramsci, A. (1971): Selections from Prison Notebooks. London.

Habermas, J. (1982): A Reply to my Critics, i J.B. Thompson og D. Held (eds.): Habermas, Critical Debates. London.

Hoff, J. (1985a): Den moderne klasseanalyse og de offentligt ansatte. Arbejdspapir. Inst. for Samf.fag og Forvaltning. K.U. Upubliceret.

Hoff, J. (red.) (1985b): Stat, kultur og subjektivitet. Elementer til en moderne klasseanalyse. København.

Hoff, J. og Goul Andersen, J. (1986): Klassestrukturelle forandringer og reformismens krise. GRUS nr. 17.

Jessop, B. (1982): The Capitalist State. Oxford.

Jessop, B. (1983): State, Accumulation Strategies and Hegemonic Projects. Kapitalistate no. 10/11.

Korsch, K. (1974): Revolutionær Videnskab, København.

Laclau, E. (1977): Politics and Ideology in Marxist Theory. Thetford.

Laclau, E. og Mouffe, C. (1985): Hegemony and Socialist Strategy. Towards a Radical Democratic Politics. London.

Lukacs, G. (1971): History and Class Consciousness. London.

Marx, K. (1974): Den tyske ideologi. Filosofiens elendighed. København.

Mouffe, C. (ed.) (1979): Gramsci and Marxist Theory. London.

Nørretranders, T. (1985): Det udelelige. København.

Offe, C. (1985): Bemerkungen zur spieltheoretischen Neufassung des Klassenbegriffs bei Wright und Elster. PROKLA nr. 58.

Parkin, F. (1979): Marxism and class theory: A bourgeois critique. London.

Poulantzas, N. (1973): Political Power and Social Classes. London.

Poulantzas, N. (1977): Den moderna kapitalismens klassestruktur. Avesta.

Poemer, J. (1982a): A General Theory of Exploitation and Class. Cambridge. Mass.

Roemer, J. (1982b): New Directions in the Marxian Theory of Exploitation and Class. Politics and Society. Vol. 11 no. 3.

Roemer, J. (1982c): Reply. Politics and Society. Vol. 11 no. 3.

Wright, E.O. (1978): Class, Crises and the State. London.

Wright, E.O. (1985): National Science Foundation Proposal 1985. Comparative Project on Class Structure and Class Consciousness. Technical Paper no. 7. 